\title{
KLAUSA BAHASA SIANG
}

\section{(SIANG LANGUAGE CLAUSE)}

\section{Elisten Parulian Sigiro}

\author{
Balai Bahasa Provinsi Kalimantan Tengah \\ Jalan Tingang Km 3,5, Palangkaraya, Kalimantan Tengah, Indonesia \\ Pos-el: giro_pky@yahoo.com
}

Diterima: 24 Februari 2015; Direvisi: ... Disetujui: ...

\begin{abstract}
This research is about a clause of Siang language. The method applied in this research is descriptive qualitative method as the method and technique of this research reflect the reality based on the facts on the field. Therefore, the results of this research try to describe objectively and precisely aspects of Siang language clause in accordance with the conditions of Siang language today, particularly regarding the characteristics, types, patterns, and relationships in complex sentences in clauses Siang language. The results of this study indicate that the phrase categories of filler predicate clause in naming Siang language in general is a) the nominal clause, $b$ ) verbal clause, c) adjectival clause, d) prepositional clauses, e) numeral clause, and f) pronouns clause. Meanwhile, adverbial clause can not fill the predicate function. Free clause in Siang language predicate can be filled by a noun phrases, verbal phrases, adjectival phrases, prepositional phrases, and numeral phrases. Characteristic of free clause is that it has the potential to stand alone as a free sentence. Meanwhile, bound clause in Siang language containing in a complex sentence consisting of two clauses or more. In this case, the relationship between the clauses one another in complex sentences can be a subordinate relationship or coordinative relations.
\end{abstract}

Keywords: Siang language, clause, sentence compound

\begin{abstract}
Abstrak
Penelitian ini adalah penelitian tentang klausa bahasa Siang. Untuk itu, metode yang digunakan dalam penelitian ini adalah metode deskriptif kualitatif karena metode dan teknik penelitian ini mencerminkan kenyataan berdasarkan fakta-fakta (fact findings) yang ada di lapangan sebagaimana adanya. Dengan demikian, hasil penelitian ini berusaha menggambarkan secara objektif dan tepat aspek klausa bahasa Siang sesuai dengan kondisi bahasa Siang saat ini, khususnya mengenai ciri, tipe, dan pola, serta hubungan antarklausa dalam kalimat majemuk bahasa Siang. Adapun hasil penelitian ini menunjukkan bahwa berdasarkan kategori frasa pengisi predikatnya penamaan klausa bahasa Siang pada umumnya adalah a) klausa nominal, b) klausa verbal, c) klausa adjektival, d) klausa preposisional, e) klausa numeralia, dan f) klausa pronominal. Sementara itu, klausa adverbial tidak dapat mengisi fungsi predikat. Klausa bebas dalam bahasa Siang predikatnya dapat diisi oleh frasa nominal, frasa verbal, frasa adjektival, frasa preposisional, dan frasa numeralia. Ciri khas klausa bebas adalah memiliki potensi untuk berdiri sendiri sebagai kalimat bebas. Sementara itu, klausa terikatdalam bahasa Siang terdapat pada kalimat kompleks yang terdiri dari dua klausa atau lebih. Dalam hal ini, hubungan antara klausa yang satu dengan yang lain dalam kalimat kompleks dapat berupa hubungan subordinatif atau hubungan koordinatif.
\end{abstract}

Kata kunci: bahasa Siang, klausa, kalimat majemuk 


\section{Pendahuluan}

Bahasa Siang merupakan salah satu bahasa daerah yang ada di Kalimantan Tengah. Berdasarkan hasil penelitian tentang struktur bahasa Siang yang dilakukan oleh Santoso dkk. (1996), bahasa ini dipakai oleh penuturnya di Kecamatan Permata Intan, Kecamatan Sumber Barito dan beberapa desa di Kecamatan Murung dan Kecamatan Laung Tuhup. Wilayah itu semua termasuk Kabupaten Barito Utara, Provinsi Kalimantan Tengah. Hingga saat ini bahasa Siang masih dipakai secara aktif oleh pemiliknya, terutama dalam situasi yang tidak resmi. Dalam situasi resmi, bahasa Siang dipakai dalam rapat-rapat desa atau pertemuan adat yang dihadiri oleh penduduk Siang. Di samping itu, bahasa Siang juga dipakai dalam tradisi sastra lisan, misalnya nyanyian-nyanyian rakyat atau cerita-cerita rakyat. Dalam hubungannya dengan pengajaran, bahasa Siang juga dipakai sebagai bahasa pengantar di sekolah dasar. Penggunaan bahasa Siang di sekolah dasar ini dari kelas satu dan berlangsung sampai murid-murid mampu menggunakan bahasa keduanya, yaitu bahasa Indonesia.

Situasi kebahasaan bahasa Siang memperlihatkan adanya pengaruh bahasabahasa daerah lain terhadap bahasa Siang. Pengaruh yang paling besar adalah dari bahasa Dayak Ngaju dan bahasa Maanyan yang mempunyai jumlah penutur lebih banyak dibandingkan bahasa Siang. Pengaruh dari bahasa lain itu didukung oleh sifat terbuka penutur bahasa Siang terhadap orang atau informasi dari luar, dan mobilitas penduduk Siang yang suka pergi ke luar daerah. Melihat pengaruh bahasa lain yang amat kuat inidan jumlah penutur bahasa Siang yang relatif sedikit, dikhawatirkan bahwa lama kelamaan bahasa Siang akan punah jika tidak dipelihara. Oleh karena itu, pemeliharaan terhadap bahasa Siang amat diperlukan. Penelitian ini di samping sebagai langkah pendokumentasian terhadap bahasa
Siang, juga diharapkan dapat mendukung usaha pemeliharaan itu.

Penelitian bahasa Siang yang pernah dilakukan oleh Santoso dkk. (1996) memerikan struktur bahasa Siang. Penelitian yang kedua, Morfologi Bahasa Siang yang dilakukan oleh Admodjo dkk. (1996) memerikan morfologi bahasa Siang. Penelitian ketiga, Fonologi Bahasa Siang dilakukan oleh Admodjo dkk. (1998) memerikan fonologi bahasa Siang. Dengan demikian, penelitian Sintaksis Bahasa Siang ini merupakan penelitian lanjutan yang akan memerikan klausa bahasa Siang. Penelitian ini di samping sebagai langkah pendokumentasian dan pemeliharaan bahasa Siang juga diharapkan bermanfaat untuk pengajaran bahasa daerah maupun pengajaran bahasa Indonesia dan dapat dijadikan sebagai alat pewarisan budaya secara tertulis sekaligus pemerkaya khasanah budaya bangsa.

Masalah bahasa yang akan dibahas dalam penelitian ini adalah masalah-masalah yang berkaitan dengan sistem klausa bahasa Siang. Masalah-masalah tersebut dapat dirumuskan, sebagai berikut. Pertama, bagaimana ciri, tipe, dan pola struktur klausa bahasa Siang? Kedua, bagaimana hubungan antarklausa dalam kalimat majemuk bahasa Siang?

Penelitian ini secara umum bertujuan mengumpulkan data, mengolah, dan mendeskripsikan secara mendalam dan terperinci mengenai sistem sintaksis bahasa Siang. Secara rinci tujuan penelitian ini untuk mendeskripsikan 1) ciri, tipe dan pola struktur klausa bahasa Siang, dan 2) hubungan antarklausa dalam kalimat majemuk bahasa Siang.

\section{Kerangka Teori}

Klausa ialah satuan gramatikal berupa kelompok kata yang sekurang-kurangnya terdiri atas subjek dan predikat, dan mempunyai potensi untuk menjadi kalimat 
(Kridalaksana dkk., 2001:208). Sementara itu, Chaer (2007:233) menyatakan bahwa klausa adalah satuan sintaksis berupa runtunan kata-kata berkonstruksi predikatif. Artinya, di dalam konstruksi itu ada komponen, berupa kata atau frase, yang berfungsi sebagai predikat; dan yang lain berfungsi sebagai subjek, sebagai objek, dan sebagai keterangan. Selain fungsi predikat yang harus ada dalam konstruksi klausa ini, fungsi subjek boleh dikatakan bersifat wajib, sedangkan yang lainnya bersifata tidak wajib. Selanjutnya, Ramlan (2001:62) mengatakan bahwa unsur inti klausa adalah $S$ dan P. Akan tetapi, S juga sering tidak dimunculkan, misalnya dalam kalimat luas sebagai akibat dari penggabungan klausa dan kalimat jawaban.

Dari definisi tersebut dapat ditarik kesimpulan bahwa klausa adalah satuan gramatik yang terdiri atas predikat, baik diikuti oleh subjek, objek, pelengkap, keterangan atau tidak dan merupakan bagian dari kalimat. Penanda klausa adalah predikat, tetapi yang menjadi klausa bukan hanya predikat. Jika mempunyai subjek, klausa terdiri atas subjek dan predikat. Jika tidak mempunyai subjek, klausa terdiri atas predikat dan objek. Jika tidak memiliki objek, klausa terdiri atas predikat dan keterangan. Dengan demikian, penanda klausa adalah predikat, tetapi yang dianggap sebagai unsur inti klausa adalah subjek dan predikat.

Jenis klausa dapat diperbedakan berdasarkan strukturnya dan berdasarkan kategori segmental yang menjadi predikatnya. Berdasarkan strukturnya dapat dibedakan adanya klausa bebas dan klausa terikat. Yang dimaksud dengan klausa bebas adalah klausa yang mempunyai unsur-unsur lengkap,sekurang-kurangnya mempunyai subjek dan predikat; dan karena itu, mempunyai potensi untuk menjadi kalimat mayor. Berbeda dengan klausa bebas yang mempunyai struktur lengkap, maka klausa terikat memiliki struktur yang tidak lengkap. Unsur yang ada dalam klausa ini mungkin hanya subjek saja, mungkin hanya objeknya saja, atau juga hanya berupa keterangan saja. Oleh karena itu, klausa terikat ini tidak mempunyai potensi untuk menjadi kalimat mayor. Umpamanya, konstruksi tadi pagi yang menjadi kalimat jawaban untuk kalimat tanya: Kapan nenek membaca komik? Selanjutnya, Chaer juga mengatakan bahwa klausa terikat biasanya dapat dikenali dengan adanya konjungsi subordinatif di depannya. Klausa terikat yang diawali dengan konjungsi subordinatif biasanya dikenal dengan nama klausa subordinatif, atau klausa bawahan. Sedangkan klausa lain yang hadir bersama dengan klausa bawahan itu di dalam sebuah kalimat majemuk disebut klausa atasan atau klausa utama (Chaer, 2007:235-236).

Berdasarkan kategori unsur segmental yang menjadi predikatnya, klausa dapat dibedakan atas klausa verbal (klausa yang predikatnya berkategori verba). Sesuai dengan adanya tipe verba, dikenal adanya (a) klausa transitif (klausa yang predikatnya berupa verba transitif); (b) klausa intransitif (klausa yang predikatnya berupa verba intransitif); (c) klausa refleksif (klausa yang predikatnya berupa verba refleksif); (d) klausa resiprokal (klausa yang predikatnya berupa verba resiprokal. Klausa nominal (klausa yang predikatnya berupa nomina atau frase nominal). Klausa adjektival (klausa yang predikatnya berkategori adjektiva, baik berupa kata maupun frase adjektiva). Klausa adverbial (klausa yang predikatnya berupa frase yang berkategori adverbia). Klausa numeral (klausa yang predikatnya berupa kata atau frase numeralia) (Chaer, 2007).

Penelitian ini menggunakan tiga dasar untuk mengklasifikasikan klausa bahasa Dayak Ngaju. Ketiga dasar itu, yakni1) klasifikasi klausa berdasarkan struktur internnya; mengacu pada hadir tidaknya 
unsur inti klausa, yaitu subjek (S) dan predikat $(\mathrm{P})$. Dengan demikian, unsur klausa yang bisa tidak hadir adalah $\mathrm{S}$ sedangkan $\mathrm{P}$ sebagai unsur inti klausa selalu hadir, 2) klasifikasi klausa berdasarkan ada tidaknya unsur negasi yang menegatifkan predikat; unsur negasi yang dimaksud adalah tidak, bukan, belum, dan jangan, dan 3) klasifikasi klausa berdasarkan kategori frasa yang menduduki fungsi predikat; klausa ini dapat diklasifikasikan menjadi: a) klausa nominal, b) klausa verbal, c) klausa adjektival, d) klausa adverbial, e) klausa numeralia, f) klausa preposisional, dan g) klausa pronominal.

\section{Metode Penelitian}

Metode yang digunakan dalam penelitian ini adalah metode deskriptif kualitatif karena metode dan teknik penelitian ini mencerminkan kenyataan berdasarkan fakta-fakta (fact findings) yang ada di lapangan sebagaimana adanya (Nawawi dan Hadari, 1967). Dengan demikian, hasil penelitian ini berusaha menggambarkan secara objektif dan tepat aspek klausa bahasa Siang sesuai dengan kondisi bahasa Siang saat ini.

Data penelitian dikumpulkan dengan metode pengumpulan data yang disebut oleh Sudaryanto (1988) sebagai metode simak dan metode cakap. Dengan metode simak, pengumpulan data dilakukan dengan penyimakan penggunaan bahasa Siang, baik dengan terlibat secara langsung dalam pembicaraan maupun tidak. Kedua penyimakan itu disebut teknik simak libat cakap. Metode simak dengan kedua teknik ini kemudian dilengkapi dengan teknik perekaman dan pencatatan.

Dengan metode cakap, pengumpulan data dilakukan melalui percakapan dan kontak antara peneliti dengan penutur selaku narasumber. Pengumpulan data dengan metode cakap ini dilakukan dengan teknik pancing (alisitasi), teknik semuka, teknik cakap semuka (kuesioner), dan teknik rekam dan teknik catat. Dengan penggunaan kedua metode pengumpulan data beserta teknikteknik yang mengikutinya, hasil akhir yang didapat adalah data tuturan bahasa Siang yang telah terekam dan tercatat secara baik.

Sementara itu, dalam analisis data, data yang terekam dan tercatat secara baik lalu diklasifikasi dan dianalisis. Analisis sintaksis dilakukan dari unsur terbesarsatuan sintaksis, yaitu kalimat, dapat pula dilakukan dari unsur terkecil satuan sintaksis, yaitu frasa. Dalam penelitian ini analisis terhadap sistem sintaksisdimulai dari satuan klausa dengan cara analisis seperti itu maka data penelitian akan dianalisisdengan langkahlangkah analisis sebagai berikut.

Pertama, ujaran-ujaran yang telah tercatat dan terekam diklasifikasi dan dipilah-pilah supaya menjadi satuan-satuan ujaran yang lengkap dan bermakna sehingga jelas batas kalimat yang satu dengan yang lain dalam sebuah wacana. Pada tahap ini penerjemahan satu demi satu dan penerjemahan berdasarkan makna dalam konteks juga harus dilakukan. Kedua, kalimat-kalimat yang telah didapat dari hasil klasifikasi ditata dan diklasifikasi kembali menjadi sebuah data yang siap dianalisis. Ketiga, analisis klausa juga memanfaatkan data siap analisis. Data kalimat dipecah hingga dihasilkan unsur-unsur klausanya. Setelah itu klausa-klausa yang didapat dianalisis secara mendalam dan terinci.Selanjutnya, hasil analisis disajikan dalam bentuk deskripsi mengenai klausa bahasa Siang.

Terkait dengan sumber data penelitian ini, mengingat penelitian ini adalah penelitian lanjutan yang dilakukan oleh Santoso dkk. (1986) dan Admodjo dkk. (1996, 1998) maka sumber data dalam penelitian ini disesuaikan dengan penelitian sebelumnya. Hal ini dilakukan agar terjadi kesinambungan dan keselarasan dengan penelitian sebelumnya. 
Santoso (1986) dan Admodjo $(1996,1998)$ telah menetapkan bahwa desa Tumbang Nangu, Saripoi, Tumbang Ulu, dan Matiat Pari sebagai sumber data penelitiannya karena diperkirakan keempat desa itu merupakan pusat daerah asal bahasa Siang. Oleh karena itu, sumber data penelitian ini adalah tuturan bahasa Siang yang dipakai oleh penuturnya di empat desa di atas. Untuk memperoleh data ini diperlukan beberapa narasumber. Narasumber ditentukan dengan beberapa kriteria, yaitu (1) narasumber adalah orang Siang asli, berusia 40 tahun ke atas, memiliki alat ucap yang normal, dan relatif tidak sering ke luar daerah, (2) narasumber lahir di desa sumber data dan bertempat tinggal di desa itu hingga sekarang. Seperti yang dikemukakan pada metode dan teknik, di samping data primer juga digunakan data sekunder.

\section{Pembahasan}

\subsection{Pengantar}

Klausa merupakan satuan gramatikal berupa kelompok kata yang sekurangkurangnya terdiri dari subjek dan predikat, dan mempunyai potensi untuk menjadi kalimat (Kridalaksana, 2001). Ramlan (2001) menambahkan bahwa unsur klausa yang selalu ada adalah predikat, sehingga klausa disebut juga konstruksi yang predikatif. Dalam kaitannya dengan klausa bahasa Siang, ketentuan-ketentuan di atas akan dibahas tentang 1) ciri, tipe dan pola klausa berdasarkan kategori frasa pengisi predikatnya, 2) klausa negatif dan klausa positif, dan 3) klausa bebas dan klausa terikat.

\subsection{Ciri, Tipe, dan Pola Klausa Berdasarkan Kategori Frasa Pengisi Predikatnya}

Berdasarkan kategori frasa pengisi predikatnya penamaan klausa bahasa Siang pada umumnya adalah klausa nominal, klausa verbal, klausa adjektival, klausa preposisional, klausa numeralia, dan klausa pronominal. Sementara itu, klausa adverbial tidak dapat mengisi fungsi predikat.

\subsubsection{Klausa Nominal}

Klausa nominal merupakan klausa yang predikatnya diisi oleh frasa nominal. Dalam bahasa Siang ditemukan klausa jenis ini yang kemungkinan antara subjek dan predikatnya dapat disisipi kata ialah/adalah.

Data (01)

tinaikuh dulun Ngaju

'ibuku (ialah) orang Ngaju'

tonyoapkuh tonyoap kayu

'gubukku (adalah) gubuk kayu'

lopou cotuh lopou ontu

'rumah ini (adalah) rumah hantu'

\subsubsection{Klausa Verbal}

Klausa ini adalah klausa dengan predikat berupa verbal. Secara umum klausa dalam bahasa Siang dapat berupa verba transitif, bitransitif, taktransitif, verba berpelengkap, verba aktif, maupun verba pasif.

Data (02)

1) Klausa verbal transitif

Sangumang nungku uluh eh

'Sangumang menanak nasinya'

Are paluh muhut uoi

'ia terus menarik rotan'

2) Klausa verbal bitransitif

dai akuh mihi iko anakkuh Putir Busu

'nanti saya beri kamu anakku Putri Bungsu'

aku mihi tombakmuh ma bulou

'saya beri upahmu dengan emas' 
tamai mehen ocin ina inekuh

'ayah membawa ikan untuk ibuku'

3) Klausa verbal berpelengkap iroh tokoru murek cohu ngayap akuh 'mereka lari hilir mudik mencari saya'

ama bokirim surat

'paman berkirim surat'

akuh jere bolajar basa Siang

'aku akan belajar bahasa Siang'

4) Klausa verbal intransitif akuh ngisok inyanmoh sorolunju 'saya bertanya di mana tertombak'

akuh pongoluku co bahat

'saya perokok yang berat'

ama nangih jorung

'paman menangis sedih'

5) Klausa verbal aktif

Edo mosi ocin

'Edo memancing ikan'

tamai nyangkul tana

'ayah mencangkul tanah'

iroh ngayap akuh

'mereka mencari saya'

6) Klausa verbal pasif

akuh tonyangit tamai

'saya dimarahi ayah'

paroi tonuruk awi tarim

'padi dicabut oleh adik'

daan karang tongaragaji awi tamai

'dahan durian digergaji oleh ayah'

\subsubsection{Klausa Adjektival}

Dalam bahasa Siang predikat klausa diisi oleh frasa adjektival yang dapat disertai adverbia sebagai pewatasnya. Subjek lazimnya diisi oleh frasa nominal dengan predikat komplemen yang diisi oleh frasa adjektival.

Data (03)

likuteh poroh

'punggungnya sakit'

babimuh bolunyak

'rambutmu subur'

amaeh arohsangit ondo otuh

'pamannya tidak marah hari ini'

kuhungeh porohsonga

'kepalanya pusing'

\subsubsection{Klausa Preposisional}

Klausa ini merupakan klausa yang fungsi predikatnya diisi oleh frasa preposisional. Dalam bahasa Siang frasa semacam ini terletak di sebelah kanan frasa nomina yang mengisi fungsi subjek klausa.

Data (04)

akuh tantirui ayam pangkuan tinangkuh

'aku tertidur di atas pangkuan ibuku'

akuh noto ma hunjung hia arah atop

'aku menengok ke atas ke arah pintu'

kaih hobelei inyan pulokayu

'kami berburu di hutan'

are hingkan lopou

'mereka dari rumah'

\subsubsection{Klausa Numeralia}

Dalam bahasa Siang frasa numeralia yang mengisi fungsi predikat berada di sebelah kanan frasa nomina yang mengisi fungsi subjeknya. 
Data (05)

peakeh limo uong

'ayamnya lima ekor'

anak ama duo dulun

'anak paman dua orang'

krowokuh duo uong

'kerbauku dua ekor'

4.3 Ciri, Tipe, dan Pola Klausa

Berdasarkan Ada atau Tidak Unsur

Negatif yangMenegatifkan Predikat

Berdasarkan ada atau tidaknya unsur negatif yang menegatifkan predikat atau mengingkarkan predikat, klausa dalam bahasa Siang digolongkan menjadi dua, yaitu klausa positif danklausa negatif.

\subsubsection{Klausa Positif}

Klausa positif adalah klausa yang tidak memilikiunsur negatif (kata negatif dan ingkar) yang menegatifkan atau mengingkarkan predikat. Predikat dalam klausa ini dapat diisi oleh frasa nominal, frasa verbal, frasa adjektival, frasa preposisional atau frasa numeralia, maupun frasa pronominal. Hal itu dapat dilihat pada data (06) berikut.

Data (06)

uluheh jari kosok

'nasinya jadi masak'

anak iyoh Putir Busu araieh

'anak itu Putri Bungsu namanya'

Sangumang nampa buwu opat

'Sangumang membuat bubu empat'

Kaih kawan lehoi non malom

'kami para bujang kemarin'

\subsubsection{Klausa Negatif}

Klausa ini merupakan klausa yang memiliki unsur negatif atau ingkar (kata negatif atau ingkar) yang dapat menegatifkan atau mengingkarkan fungsi predikat. Dalam bahasa Siang kata negatif atau kata ingkar yang dapat menegatifkan atau mengingkarkan predikat adalah oroh 'tidak', bakon 'bukan', kinai 'belum', dan aroh 'jangan'.

Data (07)

akuh oroh kuman

'saya tidak makan'

tamaikuh kinai bulik

'ayahku belum pulang'

ari bakon ajuhkuh

'dia bukan nenekku'

\subsection{Klausa Bebas dan Klausa Terikat \\ 4.4.1 Klausa Bebas}

Klausa bebas dalam bahasa Siang predikatnya dapat diisi oleh frasa nominal, frasa verbal, frasa adjektival, frasa preposisional, dan frasa numeralia. Ciri khas klausa ini adalah memiliki potensi untuk berdiri sendiri sebagai kalimat bebas.

Data (08)

akuh nyan dahat reoh-reoh

'saya ini sedang santai-santai'

Rudi non ongko Rendi

'Rudi itu kakak Rendi'

Peakkuh limo uong

'ayamku lima ekor'

\subsubsection{Klausa Terikat}

Klausa jenis ini terdapat pada kalimat kompleks yang terdiri dari dua klausa atau lebih. Dalam hal ini, hubungan antara klausa yang satu dan yang lain dalam kalimat kompleks itu dapat berupa hubungan 
subordinatif atau hubungan koordinatif. Klausa terikat yang terdapat dalam struktur subordinasi bahasa Siang adalah klausa relatif atau klausa adjektival, klausa adverbial, dan klausa komplemen.

\subsubsection{Klausa Relatif atau Klausa Adjektival}

Klausa jenis ini merupakan klausa yang berfungsi sebagai pewatas frasa nominal dalam klausa utama, dan karena sebagai pewatas inilah maka klausa relatif disebut juga klausa adjektival. Dalam bahasa Siang, penanda klausa relatif yang lazim adalah co 'yang'.

Data (09)

anak co solawar bobilem non dahat murah 'anak yang celana hitam itu sedang menyapu'

ocin co bahai non tonyihoi tinangkuh

'ikan yang besar itu dipanggang ibuku'

bawe co balou ombu non dahat kuman 'perempuan yang rambut panjang itu sedang makan'

\subsubsection{Klausa Adverbial}

Jenis klausa terikat yang lain adalah klausa adverbial. Dikatakan demikian karena klausa ini menggantikan kata atau frasa yang berfungsi sebagai adverbial yaitu fungsi keterangan meskipun seringkali dalam bahasa tertentu, fungsi keterangan tidak selalu diisi oleh kata atau frasa adverbial seperti keterangan tempat, waktu, maksud, kondisi. Klausa adverbial mengandung preposisi. Dalam bahasa Siang, klausa seperti ini dapat dilihat seperti data berikut.

Data (10)

tinai monyangit akuh tului akuh ngoyelok 'ibu memarahi aku kerena aku nakal' dahat ari buli kaih tulak hiya pulokayu

'ketika ia pulang kami pergi ke hutan'

jaka iko sangit maka akuh tulak

'jika kamu marah maka saya pergi'

\subsubsection{Klausa Komplemen}

Klausa jenis ini merupakan klausa yang menggantikan nominal atau frasa nominal. Frasa nominal ini lazimnya mengisi fungsi subjek, objek atau pelengkap dari verba dalam klausa utama. Berdasarkan data yang dikumpulkan, dalam bahasa Siang terdapat tiga macam klausa komplemen,yaitu kluasa komplemen yang mengisi fungsi subjek, objek, dan pelengkap. Jika klausa komplemen itu pengisi fungsi pelengkap, klausa komplemen dapat disisipi atau ditandai dengan konjungsi amun 'kalau/bahwa'.

Data (11)

ari mantun amun tinaieh poroh

'ia berkata kalau ibunya sakit'

ari kosuwan soun are nahat inyan intin 'ia bercerita dahulu mereka menebas di situ'

\subsection{Hubungan Antarklausa dalam Kalimat Majemuk}

Kalimat yang terdiri atas dua klausa atau lebih disebut kalimat majemuk. Oleh karena itu, terdapat dua klausa atau lebih dalam suatu kalimat. Dengan demikan, hubungan antara klausa-klausa itu ditandai oleh konjungsi pada awal salah satu klausa tersebut. Ada tiga parameter untuk membedakan hubungan tersebut, yaitu 1) komposisi internal klausa,2) hubungan struktural antarklausa, dan 3) hubungan semantik antarklausa.

Sejalan dengan tujuan penelitian ini, parameter analisis untuk membedakan hubungan antarklausa dalam kalimat manjemuk, yakni 1) hubungan struktural 
antarklausa dan 2) hubungan semantis antarklausa.

\subsubsection{Hubungan Struktural Antarklausa}

Berdasarkan hubungan strukturalnya diketahui bahwa klausa-klausa dapat dihubungkan dengan dua cara, yaitu dengan koordinasi dan subordinasi, sehingga dihasilkan kalimat koordinatif dan kalimat subordinatif.

\subsubsection{Kalimat Koordinatif}

Kalimat koordinatif merupakan kalimat majemuk yang terdiri atas dua klausa bebas atau lebih yang masing-masing klausa memiliki kedudukan sejajar. Hubungan antarklausa yang satu dengan yang lain dihubungkan oleh konjungsi koordinasi. Dalam bahasa Siang konjungsi koordinatif adalah hantang 'dan', tapi'tetapi', atau 'atau'.

Data (12)

Dani tuot hantang akuh tirui

'Dani duduk dan aku tidur'

Roni jorih tapi akuh porohsonga

'Roni gembira tapi aku gelisah'

Tamai tulak hiya pulokayu tapi akuh tirui nyan lopou

'ayah pergi ke hutan tetapi saya tidur di rumah'

\subsubsection{Kalimat Subordinatif}

Kalimat ini merupakan kalimat majemuk yang terdiri atas satu atau lebih klausa terikat yang disematkan pada sebuah klausa bebas, sehingga kalimat subordinatif terdiri atas satu klausa bebas sebagai klausa utama dan satu atau lebih klausa subordinatif yang disematkan/terikat padanya. Antara klausa yang satu dengan yang klausa yang lain dihubungkan oleh konjungsi. Dalam bahasa Siang konjungsi subordinatif itu adalah co 'yang', ocop 'sudah/telah', jaka 'bilamana/jika'.

Data (13)

Ocin co tomehen tamai dahat tonyehei tinangkuh

'Ikan yang dibawa ayah sedang dipanggang ibuku'

Akuh tulak jaka tarimkuh tirui

'Saya berangkat jika adikku tidur'

Eko ocop bulik jaka tinangeh sangit

'Eko telah pulang bilamana ibunya marah'

\subsubsection{Hubungan Semantik Antarklausa}

4.5.2.1 Hubungan Semantik Antarklausa dalam Kalimat Koordinatif

Dalam kalimat koordinatif atau kalimat majemuk setara bahasa Siang ditemukan tiga macam hubungan semantik antarklausa, yaitu hubungan penjumlahan, hubungan perlawanan, dan hubungan pemilihan.

\subsection{Hubungan Penjumlahan}

Hubungan penjumlahan ini menyatakan hubungan kegiatan, keadaan peristiwa, atau proses. Dalam bahasa Siang hubungan semacam ini ditandai dengan konjungsi subordinatif hantang 'dan'.

Data (14)

akuh hantang tarim tulak ingkat pulokayu

'saya dan adik pergi ke hutan'

Dedi mehen posi hantang tarimeh mehen ocin

'Dedi membawa kail dan adiknya membawa ikan'

piakkuh tolu uong hantang lomukuh duo uong

'ayamku tiga ekor dan lembuku dua ekor' 


\subsection{Hubungan Perlawanan}

Hubungan ini menyatakan bahwa apa yang dinyatakan dalam klausa pertama berlawanan atau tidak sama dengan klausa kedua. Dalam bahasa Siang hubungan ini ditandai dengan koordinator tapi 'tetapi'.

Data (15)

Akuh tirui tapi tinangkuh orohinai tirui

'Saya tidur tetapi ibuku belum tidur'

Sangumang ocop bulik tapi Mahanji aroko bulik

'Sangumang sudah pulang tetapi Mahanji tidak pulang'

Dadau nukat kayu tapi tinangeh sangit

'Dadau naik pohon tetapi ibunya marah'

\subsection{Hubungan Pemilihan}

Hubungan ini menyatakan pilihan di antara dua kemungkinan yang dinyatakan oleh kedua klausa yag dihubungkan. Dalam bahasa Siang hubungan semantik semacam ini ditandai dengan koordinator atau 'atau'

Data (16)

Iko inyan lopou atau tulak hiya pulokayu 'kamu di rumah atau pergi ke hutan'

Ama mosi atau hobelei

'Paman memancing atau berburu'

\subsubsection{Hubungan Semantik Antarklausa dalam Kalimat Subordinatif \\ 4.5.2.2.1 Hubungan Waktu}

Dalam hubungan ini klausa sematan menyatakan waktu terjadinya peristiwa atau keadaan yang dinyatakan dalam klausa utamanya. Dalam bahasa Siang ditemukan tiga subordinator yang menyatakan hubungan waktu antara klausa sematan dan klausa utamanya, yaitu dahat 'ketika/sedang', ingkan 'sejak', dan opah 'setelah/sesudah'.
Data (17)

Sangumang nyalan hingkan nguap ondou moharang angko ondou

'Sangumang berjalan dari pagi hari sampai siang hari'.

Akuh tirui dahat tinangkuh bulik

'Aku tidur ketika ibuku pulang'

Opah tulak hobelei, are paluh tirui

'Setelah berangkat berburu dia terus tidur'

\subsection{Hubungan Syarat}

Klausa sematan dalam hubungan ini menyatakan syarat terjadinya atau terlaksananya apa yang dinyatakan dalam klausa utamanya. Dalam bahasa Siang subordinator yang menyatakan syarat adalah amun 'jika', dan jaka 'bilamana/ seandainya'.

Data (18)

akuh tulak mosi jaka tinangkuh bulik

'saya pergi memancing jika ibuku pulang'

Dodo aroh bulik amun are nyangit

'Dodo tidak pulang jika mereka marah'

\subsection{Hubungan Penyebaban}

Klausa sematan dalam hubungan ini merupakan sebab atau alasan terjadinya sesuatu yang dinyatakan dalam klausa utamanya. Dalam bahasa Siang subordinator yang menyatakan hubungan ini adalah tului 'karena' atau awi 'sebab'.

Data (19)

akuh oroh bulik tului tinangkuh nyangit 'saya tidak pulang karena ibuku marah'

tului oroh oko posi, kaih oroh mosi

'karena tidak ada kail, kami tidak memnacing'

Mohanji oroh kuman tului oroko surupon 
'Mohanji tidak makan karena tidak ada sayur'

\subsection{Hubungan Penjelasan}

Klausa sematan menjelaskan sesuatu yag dinyatakan dalam klausa utamanya. Dalam bahasa Siang subordinator yang menyatakan hal ini lazimnya tanpa konjungsi.

Data (20)

tamai mantun tarim poroh

'ayah berkata adik sakit'

ari oroh bopikir anakeh matoi

'dia tidak berpikir anaknya meninggal'

Eko mantun arieh bulik

'Eko berkata dia pulang'

\subsection{Hubungan Atributif}

Hubungan sematan dalam hubungan ini menyatakan sesuatu atau perbuatan yang dialami atau dilakukan oleh nomina dalam klausa utamanya, sehingga klausa sematan seolah-olah menjadi pewatas (atributif) salah satu frasa nomina yang terdapat dalam klausa utamanya. Dalam bahasa Siang subordinator yang menyatakan hal ini adalah co 'yang'.

Data (21)

bawe co solawar bohenda non tarimkuh 'perempuan yang celana kuning itu adikku'

anak co lemo bobilem non mamakuh

'anak yang baju hitm itu pamanku'

belee co nungkap ocin non belee antang 'burung yang menyambar ikan itu burung elang'

\subsection{Hubungan Tujuan}

Klausa sematan dalam hubungan ini menyatakan sesuatu tujuan atau harapan dari apa yang disebut dalam klausa utamanya.
Dalam bahasa Siang subordinator dalam hubungan ini adalah $i k a$ 'supaya' pada awal klausa sematannya.

Data (22)

iko kuman ika iko oroh poroh

'kamu makan supaya kamu tidak sakit'

ika iko oroh matoi tulakleh ingkat lopou tuh 'supaya kamu tidak mati pergilah dari rumah ini'

ari paluh ngomolum apui ika lopou tuh oroh pindong

'ia lalu menghidupi api supaya rumah ini tidak gelap'

\subsection{Hubungan Perturutan}

Dalam hubungan ini klausa sematan menyatakan hubungan urutan waktu yang dinyatakan dalam klausa utamanya. Dalam bahasa Siang ditemukan subordinator yang menyatakan hubungan urutan waktu antara klausa sematan dan klausa utamanya, yaitu paluh 'lalu' pada awal klausa sematannya.

Data (23)

are monyanyi paluh anakeh tirui

'ia menyanyi lalu anaknya tidur'

are muhut uoipaluhbulik mehenuoi

'ia menarik rotan lalu membawa pulang rotan'

tamai mehen ocin paluh tinaikuh nyihoieh

'ayah membawa ikan lalu ibuku memangganya'

\section{Penutup}

Berdasarkan kategori frasa pengisi predikatnya penamaan klausa bahasa Siang pada umumnya adalah klausa nominal, klausa verbal, klausa adjektival, klausa preposisional, klausa numeralia, dan klausa pronominal. Sementara itu, klausa adverbial tidak dapat mengisi fungsi predikat. 
Klausa bebas dalam bahasa Siang predikatnya dapat diisi oleh frasa nominal, frasa verbal, frasa adjektival, frasa preposisional, dan frasa numeralia. Ciri khas klausa ini adalah memiliki potensi untuk berdiri sendiri sebagai kalimat bebas. Sementara itu, klausa terikatdalam bahasa Siang terdapat pada kalimat kompleks yang terdiri dari dua klausa atau lebih.

Hubungan antarklausa dalam kalimat majemuk bahasa Siang dibedakan dari hubungan antarklausa dalam kalimat manjemuk, yakni hubungan struktural antarklausa dan hubungan semantis antarklausa. Berdasarkan hubungan strukturalnya diketahui bahwa klausa-klausa dapat dihubungkan dengan dua cara, yaitu dengan koordinasi dan subordinasi, sehingga dihasilkan kalimat koordinatif dan kalimat subordinatif. Dalam bahasa Siang konjungsi koordinatif adalah hantang 'dan', tapi 'tetapi', atau 'atau' dan konjungsi subordinatif adalah co 'yang', ocop 'sudah/telah', jaka 'bilamana/jika'.

Sementara itu, berdasarkan hubungan semantis antaklausa, dalam kalimat koordinatif atau kalimat majemuk setara bahasa Siang ditemukan tiga macam hubungan semantik antarklausa, yaitu hubungan penjumlahan, dalam bahasa Siang hubungan semacam ini ditandai dengan konjungsi subordinatif hantang 'dan'; hubungan perlawanan, dalam bahasa Siang hubungan ini ditandai dengan koordinator tapi 'tetapi'; dan hubungan pemilihan, dalam bahasa Siang hubungan semantik semacam ini ditandai dengan koordinator atau 'atau'.

Selanjutnya, berdasarkan hubungan semantis antaklausa, dalam kalimat subordinatif bahasa Siang ditemukan tiga subordinator yang menyatakan hubungan waktu antara klausa sematan dan klausa utamanya, yaitu dahat 'ketika/sedang', ingkan 'sejak', dan opah 'setelah/sesudah'. Untuk hubungan syarat, subordinator yang menyatakan syarat ini adalah amun 'jika', dan jaka 'bilamana/seandainya'. Untuk hubungan penyebaban, subordinator yang menyatakan hubungan ini adalah tului 'karena' atau awi 'sebab'. Untuk hubungan penjelasan, subordinator yang menyatakan hal ini lazimnya tanpa konjungsi. Untuk hubungan atributif, subordinator yang menyatakan hal ini adalah co 'yang'. Sedangkan untuk hubungan tujuan, subordinator dalam hubungan ini adalah $i k a$ 'supaya' pada awal klausa sematannya dan untuk hubungan perturutan yang menyatakan hubungan urutan waktu adalah konjungsi paluh 'lalu'.

\section{Daftar Pustaka}

Admodjo dkk. (1996). Fonologi Bahasa Siang. Palangkaraya: FKIP Unpar.

(1996). Morfologi Bahasa Siang. Palangkaraya: FKIP Unpar.

Alwi, Hasan et al. (2000). Tata Bahasa Baku Bahasa Indonesia, Edisi Ketiga. Jakarta: Balai Pustaka.

Bloomfield, Leonard. (1933). Language. London: George Allen \& Unwin Ltd.

Chaer, Abdul. (2007). Linguistik Umum. Jakarta: Rineka Cipta.

Kridalaksana, Harimurti. (2001). Kamus Linguistik. Edisi Ketiga. Jakarta: Gramedia Pustaka Utama. . (1988). Beberapa Prinsip Perpaduan Leksem dalam Bahasa Indonesia. Yogyakarta: Kanisius.

(2007). Kelas Kata dalam Bahasa Indonesia. Edisi Kedua. Jakarta: Gramedia Pustaka Utama. 
Klausa Bahasa Siang (Elisten Parulian Sigiro)| 41

Lyons, E.A. (1977). Introduction to Theoretical Linguistics. Cambridge: Cambridge Univ. Press.

Nanawi dan Hadari. (1967). Metode dan Teknik Penelitian. Yokyakarta: CV Karyono.

Ramlan, M. (2001). Ilmu Bahasa Indonesia: Sintaksis. Yogyakarta: UP Karyono.
Santoso dkk. (1996). Struktur Bahasa Siang. Palangkaraya: FKIP Unpar.

Sudaryanto. (1988). Metode Linguistik: Ke Arah Memahami Metode Linguistik. Yogyakarta: UGM Press. 
42|Mabasan, Vol. 9 No.1, Januari-Juni 2015: 29-42 